\title{
Effects of seagulls on ecosystem respiration, soil nitrogen and vegetation cover on a pristine volcanic island, Surtsey, Iceland
}

\author{
B. D. Sigurdsson ${ }^{1}$ and B. Magnusson ${ }^{2}$ \\ ${ }^{1}$ Agricultural University of Iceland, 112 Keldnaholt, Reykjavik, Iceland \\ ${ }^{2}$ Icelandic Institute of Natural History, P. O. Box 5320, 125 Reykjavik, Iceland
}

Received: 26 June 2009 - Published in Biogeosciences Discuss.: 26 August 2009

Revised: 26 January 2010 - Accepted: 15 February 2010 - Published: 5 March 2010

\begin{abstract}
When Surtsey rose from the North Atlantic Ocean south of Iceland in 1963, it became a unique natural laboratory on how organisms colonize volcanic islands and form ecosystems with contrasting structures and functions. In July, 2004, ecosystem respiration rate $\left(R_{\mathrm{e}}\right)$, soil properties and surface cover of vascular plants were measured in 21 permanent research plots distributed among the juvenile communities of the island. The plots were divided into two main groups, inside and outside a seagull (Larus spp.) colony established on the island. Vegetation cover of the plots was strongly related to the density of gull nests. Occurrence of nests and increased vegetation cover also coincided with significant increases in $R_{\mathrm{e}}$, soil carbon, nitrogen and C:N ratio, and with significant reductions in soil $\mathrm{pH}$ and soil temperatures. Temperature sensitivity (Q10 value) of $R_{\mathrm{e}}$ was determined as 5.3. When compared at constant temperature the $R_{\mathrm{e}}$ was found to be 59 times higher within the seagull colony, similar to the highest fluxes measured in drained wetlands or agricultural fields in Iceland. The amount of soil nitrogen, mainly brought onto the island by the seagulls, was the critical factor that most influenced ecosystem fluxes and vegetation development on Surtsey. The present study shows how ecosystem activity can be enhanced by colonization of animals that transfer resources from a nearby ecosystem.
\end{abstract}

\section{Introduction}

Surtsey is a volcanic island that emerged from the North Atlantic Ocean in 1963 in an eruption that lasted for three years. Protection of the island as a nature reserve was established in

Correspondence to: B. D. Sigurdsson (bjarni@lbhi.is)
1965, which limited the human impact to only a few visits annually by scientists. Since then, Surtsey has been a unique laboratory to study how life colonizes isolated volcanic islands and primary succession starts. The island became a UNESCO World Heritage Site in July 2008 due to its unique geology and research activity during the past 45 years (Hermannsson, 2009).

Bacteria and fungi were probably the first organisms to become established on the volcanic substrate (e.g. Schwabe, 1970), but the first vascular plant was found on the beach in 1965 while the island was still erupting (Fridriksson, 1966). Mosses were first detected in 1968, lichens in 1970 and fungi in 1971 (Jóhannsson, 1968; Kristinsson, 1972; Eyjólfsdóttir, 2009).

Vascular plants have dominated the primary succession on Surtsey and their colonization and succession have been studied intensively (e.g. Fridriksson, 1966; Magnússon et al., 1992, 2009; Magnússon and Magnússon, 2000). The first twenty years were characterized by colonization and succession of coastal plant communities, forming sparse vegetation cover on sandy areas of the island (Fridriksson, 1992; Magnússon et al., 2009). In 1986 a few pairs of lesser blackbacked gulls (Larus fuscus) formed a small breeding colony on a lava plain on the southern part of the island (Magnússon and Magnússon, 2000; Petersen, 2009). This colony remained spatially well defined and grew in size over the next several years, with herring gulls (Larus argentatus) and great black-backed gulls (Larus marinus) moving in. In 2003, ca. 300 pairs of gulls bred on the island (Petersen, 2009), most of them within the colony. The establishment of the gull colony had a large effect on the rate of colonization by vascular plants. By 2008 a total of 69 vascular plant species had been discovered on the island of which 63 species were found alive that year (Magnússon et al., 2009).

Published by Copernicus Publications on behalf of the European Geosciences Union. 
Ecosystem function has been less studied than ecosystem structure on Surtsey. In the early years Henriksson and Rodgers (1978) and Henriksson and Henriksson (1982) studied the terrestrial nitrogen cycle. Magnússon (1992) studied how soil respiration changed with increasing cover of Leymus arenarius and Honkenya peploides on the island. He related respiration rates to differences in vegetation cover and root biomass. Frederiksen et al. (2000) studied soil development on Surtsey and showed how microbial biomass served as a nutrient-retaining mechanism that kept nutrients from leaching out when brought in by atmospheric deposition, sea spray, nitrogen fixing microorganisms and bird droppings. This would enable vascular plants to colonize and utilize the accumulated nutrients. Klamer et al. (2000) also studied the amount of microbial biomass in bare and vegetated soil. Sigurdsson (2009) measured ecosystem carbon fluxes in swards of Leymus arenarius and Honckenya peploides growing on moist and dry micro sites on the island. This study indicated that soil moisture is also an important factor for ecosystem functioning on the island.

The rate at which nutrients are released from the dead organic matter depends on the activity of decomposition in the soil layer. As the organic matter is decomposed, $\mathrm{CO}_{2}$ is released and leaves the surface as soil respiration in a process termed heterotrophic respiration. The second major contributor of $\mathrm{CO}_{2}$ to the soil respiration is the metabolism of living plant roots in the soil. When aboveground parts of living plants are included in respiration measurements, as in the present study, $\mathrm{CO}_{2}$ from shoot metabolism is also included. Then, the process is termed ecosystem respiration $\left(R_{\mathrm{e}}\right)$. The rate of $R_{\mathrm{e}}$ depends therefore both on plant biological activity, termed autotrophic respiration, and decomposition activity of soil organisms. The $R_{\mathrm{e}}$ is therefore a measure of the ecosysterm function and, together with gross primary production (GPP), it determines the annual carbon balance and the accumulation of organic matter in the ecosystem (Grace, 2001).

Critical factors reported to influence rates of soil and ecosystem respiration include temperature, soil moisture, vegetation and substrate quality, net ecosystem productivity, the relative allocation of NPP above- and belowground, population and community dynamics of the aboveground vegetation and belowground flora and fauna, and disturbance regimes (Raich and Schlesinger, 1992; Boone et al., 1998; Rustad et al., 2000; Grace, 2001). Despite this complex array of factors, soil respiration is typically modelled as either a simple $Q 10$ function or as a step relationship based on temperature response curves (Atkin et al., 2005).

The objective of the present study was to determine how the colonization of seagulls on Surtsey has affected soil nitrogen, ecosystem respiration and vegetation cover. For this we used existing permanent plots where vegetation development has been monitored on the island since 1990 (Magnússon and Magnússon, 2000; Magnússon et al., 2009).

\section{Material and methods}

\subsection{Site desription}

Surtsey is the southernmost of the Westman Islands off the south coast of Iceland $\left(63.3^{\circ} \mathrm{N}, 20.6^{\circ} \mathrm{W}\right)$. The climate is relatively mild and oceanic, with an annual mean temperature of $5.0^{\circ} \mathrm{C}$ and mean annual precipitation of $1576 \mathrm{~mm}$ during 1965-2005, as recorded at the weather station on the island of Heimaey $15 \mathrm{~km}$ to the northeast of Surtsey (Icelandic Meteorological Office).

Surtsey emerged in an eruption that lasted from November 1963 to June 1965 . When the eruption ceased the island was $2.7 \mathrm{~km}^{2}$ of which ca. $30 \%$ consisted of rough lava surfaces and $70 \%$ was covered by loose tephra. In 2006 coastal erosion had reduced the island to $1.4 \mathrm{~km}^{2}$ (Jakobsson et al., 2007). Weathering and erosion have also greatly altered the surface of the island. The tephra cones around the two craters (Fig. 1) have gradually been transformed into a dense palagonite tuff and the rough lava has to a large extent been covered by a layer of drifting tephra and sand, which in this study is termed "soil".

\subsection{Measurements}

Measurements of ecosystem respiration $\left(R_{\mathrm{e}}\right)$ were conducted on 19-20 July 2004 in 21 permanent vegetation survey plots (Fig. 1). The plots, which are $10 \times 10 \mathrm{~m}$ in area, were set up on the island in 1990-1995 to follow the impact of the developing seagull colony on the vegetation succession (Magnússon and Magnússon, 2000). Plots 1-10 were at that time placed inside the colony while plots 11-23 were on different surfaces outside the colony (Fig. 1). In the present study in 2004 it was evident that plot 23 had become influenced by the seagulls and was therefore considered as inside the colony.

A CIRAS II infrared gas analyzer and a SP1 respiration chamber (PP Systems, UK) were used to measure $R_{\mathrm{e}}$. A $14 \mathrm{~m}$ long tape was fitted diagonally between the SW and NE corners of the plots and four respiration measurements were made within each, generally at $1 \mathrm{~m}, 4 \mathrm{~m}, 8 \mathrm{~m}$ and $11 \mathrm{~m}$ from the SW corner. In a few plots, where the respiration chamber could not be sealed due to the uneven lava surface, the measurements were made at the next suitable surface along the tape. Soil temperature was recorded at a $10 \mathrm{~cm}$ depth with a temperature probe placed adjacent to the respiration chamber. All measurements took place during daytime hours between 08:30 and 18:30.

The vegetation surface cover was measured in each permanent plot during routine sampling in 2004 by the lineintercept method as described by Magnússon and Magnússon (2000). Vegetation surface cover was also recorded under the flux measurement chamber at each measurement point. Density of gull nests was recorded in 2004 by carefully inspecting a $1000 \mathrm{~m}^{2}$ circular plot around each permanent vegetation plot (Magnússon et al., 2009). 


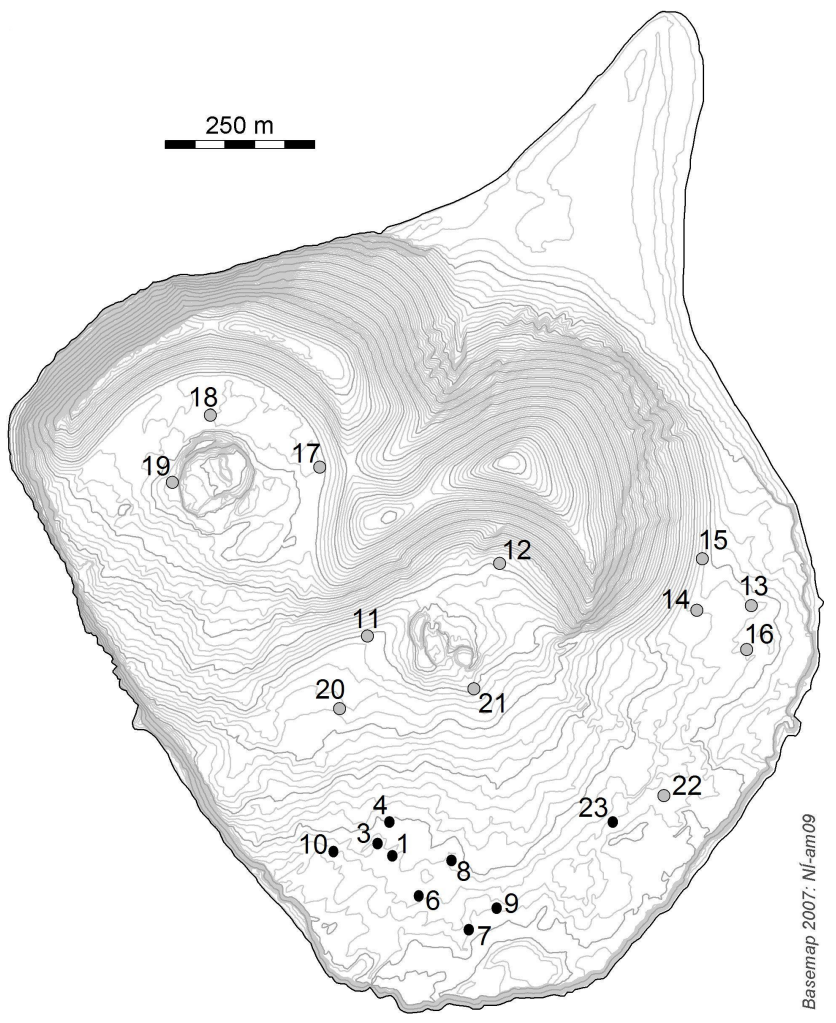

Fig. 1. Location of the 21 permanent vegetation plots on Surtsey where flux measurements were carried out in 2004, shown on a topographical map of the island from 2007. Black and grey dots indicate plots within and outside the seagull colony, respectively. Contour intervals are $2 \mathrm{~m}$, the highest point on the island being $152 \mathrm{~m}$ a.s.1.

The soil was sampled in the permanent plots in 2004 . Four $10 \mathrm{~cm}$ deep soil cores were taken at random locations within each plot and then mixed to form a composite sample. The samples were sieved through a $2 \mathrm{~mm}$ mesh and dried at $80^{\circ} \mathrm{C}$ for $48 \mathrm{~h}$ and analysed at the Centre of Chemical Analyses (Efnagreiningar Keldnaholti), ICETEC, Reykjavik, Iceland. Total $\mathrm{N}$ was analysed by Kjeldahl wet combustion with a Tecator Kjeltec Auto 1030 Analyzer. Total C was analysed by dry combustion with a Leco CR-12 Carbon Analyzer and the soil $\mathrm{pH}$ was measured by an electrode (Orion model $920 \mathrm{~A}$ ) in a soil/water mixture of 1:1.

The difference in variables measured within and outside the gull colony area was tested with one-way ANOVA in the SAS statistical program (SAS system 9.1, SAS Institute Inc., Cary, NC, USA). Normal Probability Plots of residuals were used to check that assumptions about normality were met. The relationship between soil nitrogen and vegetation cover and $R_{\mathrm{e}}$ was investigated by a linear regression in the SigmaPlot program (Version 11.0, Systat Software, Inc., San Jose, CA, USA). The regression was followed by a ShapiroWilk Normality Test on the residuals to check that the data were not significantly different from a normal distribution.
A nonlinear regression analysis in the Sigma Plot program was used to investigate the temperature response of $R_{\mathrm{e}}$ inside and outside the gull colony. For this the $R_{\mathrm{e}}$ was first scaled with the measured vegetation cover within the chamber (flux cover), resulting in $R_{\mathrm{e}}$ per unit flux cover. The temperature dependency of the $R_{\mathrm{e}}$ was determined by a simple exponential nonlinear model of the form:

$R_{\mathrm{e}} / V=R_{0} \times \exp ^{\beta \times T s}$,

Where $R_{\mathrm{e}} / V$ is the $R_{\mathrm{e}}$ per unit vegetation cover in the flux chamber, $R_{0}$ and $\beta$ are fitted parameters and $T_{\mathrm{S}}$ is the soil temperature at $10 \mathrm{~cm}$. The temperature sensitivity parameter $(Q 10)$ was derived as:

$Q 10=\exp ^{\beta \times 10}$.

Estimated $Q 10$ of $R_{\mathrm{e}} / V$ was used together with $T_{\mathrm{S}}$ to recalculate all individual $R_{\mathrm{e}}$ measurements to a common $T_{\mathrm{s}}$ $\left(15^{\circ} \mathrm{C}\right)$. This reference temperature was chosen as it was within the temperature range found in both sampling areas.

\section{Results}

The plots inside the gull colony had 3.4 nests on the average within a $1000 \mathrm{~m}^{2}$ area, while no nests were found by the plots outside the colony (Table 1). Vegetation cover was significantly greater in the plots within the gull colony than in the plots outside it, an average of $78 \%$ and 5\%, respectively. Outside the gull colony the undeveloped soil contained only $0.01 \% \mathrm{~N}$ and $0.04 \% \mathrm{C}$. The relative increase of soil $\mathrm{N}$ within the gull colony was 13 -fold and soil $\mathrm{C}$ had increased 43 -fold compared to the area outside it (Table 2). The average soil $\mathrm{C} / \mathrm{N}$ ratio increased significantly, from 5.2 outside to 12.7 within the gull colony. Soil $\mathrm{pH}$ was on average 7.03 across all plots. It was significantly lower in the more vegetated soil within the gull colony compared to the outside area, or 6.6 compared to 7.6 , respectively (Table 2 ).

Increased surface insulation by higher vegetation cover in the gull colony led to significantly lower soil temperatures there compared to the barren sand plots outside the colony. The difference was $4.6^{\circ} \mathrm{C}$ on the average (Table 1). The average vegetation cover measured in each plot in 2004 was similar to the average cover in the four fixed measurement points for ecosystem respiration $\left(R_{\mathrm{e}}\right)$ within each plot (Table 1), indicating that the four points were sufficient to cover the variation within each plot.

Ecosystem respiration was positively correlated with vegetation cover and soil $\mathrm{N}$, with a highly significant difference between the gull colony and the area outside it (Fig. 2). Plot 23, which was in an area recently colonized by the gulls, showed intermediate rates of $R_{\mathrm{e}}$.

When $R_{\mathrm{e}}$ was compared directly to soil temperature it was clear that the difference in soil temperature was not responsible for most of the differences in $R_{\mathrm{e}}$ between the two areas (Fig. 3, top panel). In order to exclude the confounding 
Table 1. Site properties of permanent study plots inside and outside a gull colony in July, 2004. Cover was measured as \% of surface area. $T_{\mathrm{S}}$ stands for soil temperature at $10 \mathrm{~cm}$ depth $\left({ }^{\circ} \mathrm{C}\right)$. Difference within and outside gull colony was tested with one-way ANOVA: ns $=P>0.05$, * $P=0.05-0.01$, ** $P=0.01-0.001, * * * P<0.001$.

\begin{tabular}{|c|c|c|c|c|c|c|c|c|}
\hline No. & $\begin{array}{l}\text { Gull } \\
\text { colony }\end{array}$ & $\begin{array}{l}\text { Nests } \\
\text { per } 1000 \mathrm{~m}^{2}\end{array}$ & $\begin{array}{l}\text { Substr. } \\
\text { type }^{a}\end{array}$ & $\begin{array}{l}\text { Key } \\
\text { plant sp. } b\end{array}$ & $\begin{array}{l}\text { Veget. } \\
\text { cover }\end{array}$ & $\begin{array}{l}\text { Camber veget. } \\
\text { cover }\end{array}$ & $\begin{array}{l}\text { Soil } \\
\text { depth }(\mathrm{cm})\end{array}$ & $\begin{array}{l}T_{\mathrm{S}} \\
\left({ }^{\circ} \mathrm{C}\right)\end{array}$ \\
\hline 1 & + & 1.0 & B & Poa pra & 98.8 & 100 & $28.7 \pm 7.2$ & 14.5 \\
\hline 3 & + & 0.5 & $\mathrm{~B}$ & Ste med & 100.0 & 100 & $>35$ & 12.8 \\
\hline 4 & + & 2.5 & B & Poa ann & 86.8 & 100 & $35.0 \pm 8.9$ & 15.0 \\
\hline 6 & + & 0.5 & A & Fes ric & 96.9 & 100 & $6.3 \pm 1.5$ & 13.3 \\
\hline 7 & + & 4.5 & $\mathrm{~A}$ & Poa pra & 86.2 & 100 & $3.5 \pm 0.5$ & 14.4 \\
\hline 8 & + & 3.0 & A & Coc off & 70.3 & 76 & $3.0 \pm 0.7$ & 15.3 \\
\hline 9 & + & 11.0 & A & Sag pro & 95.1 & 81 & $7.3 \pm 1.0$ & 14.4 \\
\hline 10 & + & 6.5 & A & Hon pep & 40.9 & 98 & $4.5 \pm 1.0$ & 12.8 \\
\hline 23 & + & 1.0 & $\mathrm{C}$ & Sag pro & 30.1 & 83 & $1.0 \pm 0.0$ & 17.9 \\
\hline \multicolumn{2}{|c|}{ Mean \pm SE } & \multicolumn{2}{|l|}{$3.4 \pm 1.2$} & & $78.3 \pm 8.7$ & $93.1 \pm 3.3$ & & $14.5 \pm 0.5$ \\
\hline 11 & - & 0 & $\mathrm{C}$ & Hon pep & 3.3 & 1 & $>35$ & 19.7 \\
\hline 12 & - & 0 & $\mathrm{C}$ & Hon pep & 23.9 & 21 & $>35$ & 17.9 \\
\hline 13 & - & 0 & B & Hon pep & 3.1 & 0 & $>35$ & 20.5 \\
\hline 14 & - & 0 & B & Hon pep & 2.4 & 0 & $23.7 \pm 8.8$ & 20.6 \\
\hline 15 & - & 0 & $\mathrm{C}$ & Hon pep & 9.8 & 20 & $>35$ & 19.2 \\
\hline 16 & - & 0 & B & Hon pep & 2.0 & 1 & $5.3 \pm 0.9$ & 20.9 \\
\hline 17 & - & 0 & B & Hon pep & 1.7 & 0 & $>35$ & 19.5 \\
\hline 18 & - & 0 & B & Car pet & 4.8 & 0 & $7.3 \pm 1.0$ & 17.8 \\
\hline 19 & - & 0 & B & Hon pep & 1.0 & 3 & $8.0 \pm 0.6$ & 19.7 \\
\hline 20 & - & 0 & B & Hon pep & 3.8 & 1 & $>35$ & 17.8 \\
\hline 21 & - & 0 & $\mathrm{~B}$ & Hon pep & 1.2 & 1 & $>35$ & 20.7 \\
\hline 22 & - & 0 & A & Sag pro & 1.0 & 1 & $2.0 \pm 0.4$ & 15.5 \\
\hline \multicolumn{2}{|c|}{ Mean \pm SE } & \multicolumn{2}{|l|}{$0 \pm 0$} & & $4.8 \pm 1.9$ & \multicolumn{2}{|l|}{$4.4 \pm 2.4$} & $19.1 \pm 0.5$ \\
\hline \multicolumn{2}{|l|}{$P$} & - & & & $* * *$ & $* * *$ & ns & $* * *$ \\
\hline
\end{tabular}

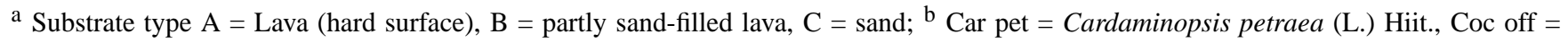
Cochlearia officinalis L., Fes ric = Festuca richardsonii Hooker, Hon peb = Honckenya peploides (L.) Ehrh., Poa ann = Poa annua L., Poa pra $=$ Poa pratensis L., Sag med = Sagina procumbens L., Ste med = Stellaria media $($ L.) Vill.

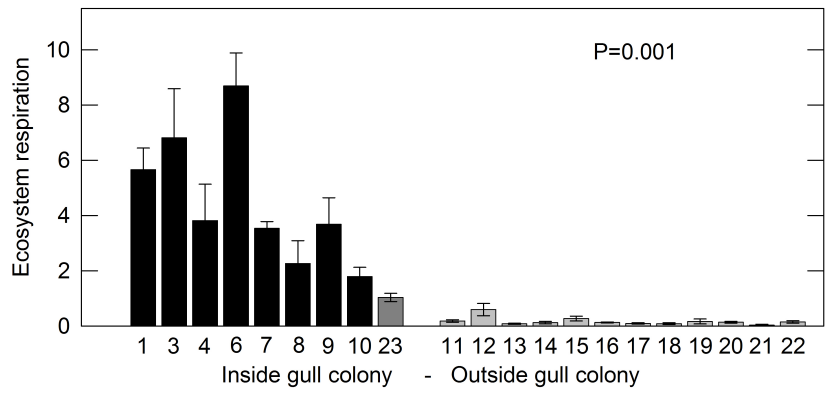

Fig. 2. Ecosystem respiration $\left(R_{\mathrm{e}} ; \mu \mathrm{mol} \mathrm{m} \mathrm{m}^{-2} \mathrm{~s}^{-1}\right.$; average of $n=$ $4 \pm \mathrm{SE})$ in the permanent vegetation plots on Surtsey. Black and light grey bars indicate plots located within and outside the gull colony, respectively. Numbers on $\mathrm{x}$-axis are plot numbers. The P-value indicates the significance of one-way ANOVA test on the difference between the two groups. effect of the difference in soil temperatures between the areas, Eq. (1) was fitted to the data to estimate $R_{\mathrm{e}}$ at the same temperature in both areas. The relationship was significant for the vegetated plots within the gull colony, but not for the more heterogeneously covered plots outside $(P=0.01$ and 0.28 , respectively; analysis not shown). To test whether the lack of a significant temperature relationship outside the gull colony was caused by variability in vegetation cover, all $R_{\mathrm{e}}$ data were expressed per unit vegetation cover $\left(R_{\mathrm{e}} / V\right)$. This step revealed a significant temperature dependence and the respiration rates converged for both areas (Fig. 3, lower panel; Table 3). The $Q 10$ of the merged temperature function was 5.3 and the variability in soil temperature explained $30 \%$ of the total variability observed in $R_{\mathrm{e}} / V$ across all plots (Table 3).

Assuming that the temperature dependence of $R_{\mathrm{e}}$ was not greatly affected by how much vegetation was present, the $Q 10$ values found for $R_{\mathrm{e}} / V$ were used to recalculate $R_{\mathrm{e}}$ to 
Table 2. Total carbon (C), pH and nitrogen (N), expressed as \% of dry soil, sampled in permanent plots on Surtsey in 2004 . Difference within and outside gull colony was tested with one-way ANOVA: ns $=P>0.05$, * $P=0.05-0.01$, ** $P=0.01-0.001$, *** $P<0.001$.

\begin{tabular}{|c|c|c|c|c|c|}
\hline No. & $\begin{array}{c}\text { Gull } \\
\text { colony }\end{array}$ & $\mathrm{pH}$ & $\begin{array}{c}\text { Total } \\
\mathrm{N}\end{array}$ & $\begin{array}{c}\text { Total } \\
\text { C }\end{array}$ & $\begin{array}{l}\mathrm{C}: \mathrm{N} \\
\text { ratio }\end{array}$ \\
\hline 1 & + & 6.81 & 0.07 & 0.87 & 13.0 \\
\hline 3 & + & 6.70 & 0.06 & 0.63 & 10.9 \\
\hline 4 & + & 6.82 & 0.04 & 0.48 & 11.3 \\
\hline 6 & + & 6.45 & 0.32 & 5.00 & 15.6 \\
\hline 7 & + & 6.35 & 0.24 & 2.83 & 11.8 \\
\hline 8 & + & 6.50 & 0.22 & 2.95 & 13.5 \\
\hline 9 & + & 6.42 & 0.12 & 1.52 & 12.9 \\
\hline 10 & + & 6.77 & 0.05 & 0.64 & 12.2 \\
\hline 23 & + & 6.33 & 0.05 & 0.65 & 12.7 \\
\hline \multicolumn{2}{|c|}{$\operatorname{Mean} \pm \mathrm{SE}$} & $6.57 \pm 0.07$ & $0.13 \pm 0.03$ & $1.73 \pm 0.52$ & $12.7 \pm 0.5$ \\
\hline 11 & - & 8.02 & 0.01 & 0.04 & 9.1 \\
\hline 12 & - & 8.03 & 0.01 & 0.05 & 7.3 \\
\hline 13 & - & 7.73 & 0.01 & 0.04 & 7.4 \\
\hline 14 & - & 7.64 & 0.00 & 0.02 & 5.1 \\
\hline 15 & - & 7.62 & 0.01 & 0.05 & 7.0 \\
\hline 16 & - & 7.31 & 0.01 & 0.04 & 6.2 \\
\hline 17 & - & 7.85 & 0.01 & 0.03 & 4.3 \\
\hline 18 & - & 7.44 & 0.01 & 0.02 & 2.5 \\
\hline 19 & - & 7.39 & 0.01 & 0.03 & 3.1 \\
\hline 20 & - & 7.95 & 0.01 & 0.04 & 3.2 \\
\hline 21 & - & 7.75 & 0.01 & 0.02 & 1.4 \\
\hline 22 & - & 6.76 & 0.02 & 0.10 & 5.8 \\
\hline \multicolumn{2}{|c|}{$\operatorname{Mean} \pm \mathrm{SE}$} & $7.59 \pm 0.11$ & $0.01 \pm 0.00$ & $0.04 \pm 0.01$ & $5.2 \pm 0.7$ \\
\hline \multicolumn{2}{|l|}{$P$} & $* * *$ & $* * *$ & $* *$ & $* * *$ \\
\hline
\end{tabular}

a common temperature of $15^{\circ} \mathrm{C}$ (Fig. 4). On average, the $R_{\mathrm{e}}$ were 4.14 and $0.17 \mu \mathrm{mol} \mathrm{CO}_{2} \mathrm{~m}^{-2} \mathrm{~s}^{-1}$ within and outside the gull colony, respectively. The temperature correction decreased the estimated $R_{\mathrm{e}}$ by $44 \%$ outside the gull colony, but increased the estimated $R_{\mathrm{e}}$ by $38 \%$ in the vegetated plots within it (Fig. 4). The $R_{\mathrm{e}}$ activity was 59 times higher in the gull colony $(P<0.001)$ after the rates had been corrected for temperature, compared to a relative difference of 24 times with no temperature correction. Hence, the elevated respiration activity observed within the gull colony was partly counteracted as soil temperature fluctuations were buffered by the lush vegetation during summer.

The soil nitrogen $(\mathrm{N})$ concentration was the most important factor included in the present study for both $R_{\mathrm{e}}$ and vegetation cover $(V)$ (Fig. 5). Other factors were also tested, including gull breeding density, soil $\mathrm{pH}, \mathrm{C}: \mathrm{N}$ ratio, soil $\mathrm{C}$ concentration, but none had as high $r^{2}$ as $\mathrm{N}$ (data not shown). The vegetation cover in the permanent plots had generally reached $100 \%$ when $\mathrm{N}$ had reached about $0.1 \%$ of soil DM. A linear regression for the plots that had less than $0.1 \%$ soil $\mathrm{N}$ showed that $78 \%$ of the observed variability in their vegetation cover could be explained by the soil $\mathrm{N}$ concentration (Fig. 5, upper panel; ANOVA, $P<0.001, r^{2}=0.78$ ):
$V=1455.41 \times \mathrm{N}-9.00$

where $\mathrm{N}$ was the soil nitrogen in the top $10 \mathrm{~cm}$ in $\%$ of DM. The model passed a normality test.

Unlike the surface cover, there was no saturation observed for $R_{\mathrm{e}}$ at higher $\mathrm{N}$ concentrations (Fig. 5, lower panel). Soil $\mathrm{N}$ explained $51 \%$ of the variability in ecosystem respiration at $15^{\circ} \mathrm{C}$ (ANOVA, $\left.P<0.001, r^{2}=0.51\right)$. The data had to be log-transformed to meet normality and constant variance requirements. The regression model when expressed on a linear scale was:

$R_{\mathrm{e}}=30.49 \times \mathrm{N}+0.63$,

where $\mathrm{N}$ was the soil nitrogen in the top $10 \mathrm{~cm}$ as $\%$ of DM.

\section{Discussion}

The importance of seabirds on ecosystem functions has been increasingly acknowledged in recent years. In areas where their colonies are found the birds can be viewed as chemical and physical engineers that affect both ecosystem structure and function through disturbance, seed dispersal and nutrient transport from sea to land (Ellis, 2005; Sekercioglu, 2006). 


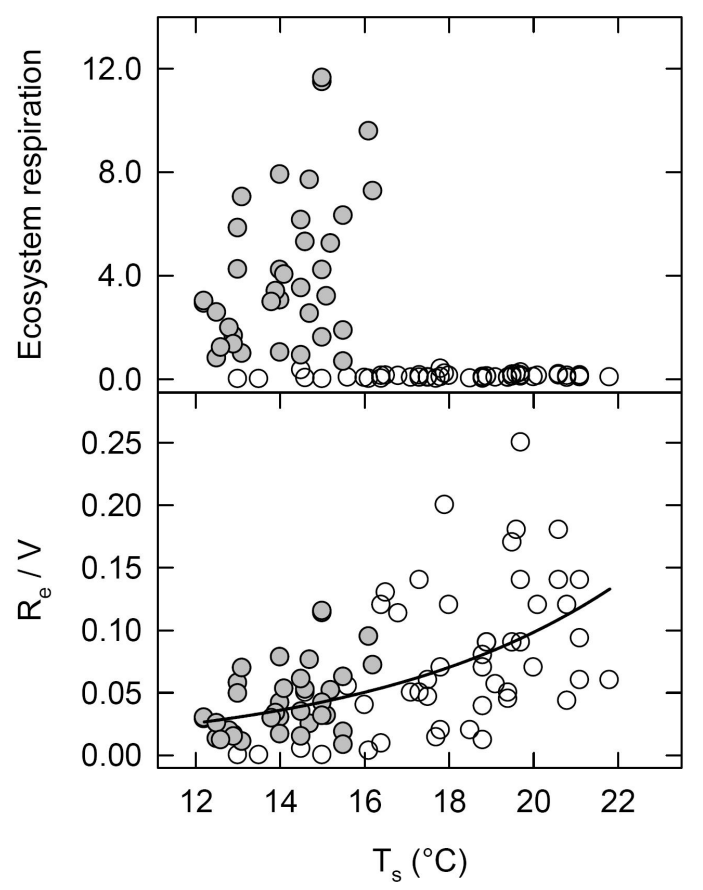

Fig. 3. Ecosystem respiration $\left(\mu \mathrm{mol} \mathrm{m} \mathrm{m}^{-2} \mathrm{~s}^{-1}\right.$; top panel) and ecosystem respiraton per unit vegetation cover $\left(R_{\mathrm{e}} / V\right.$, $\mu \mathrm{mol} \mathrm{V} \mathrm{V}^{-1} \mathrm{~m}^{-2} \mathrm{~s}^{-1}$; bottom panel) in relation to soil temperature $\left(T_{\mathrm{S}}\right)$ at $10 \mathrm{~cm}$ depth within (filled symbols) and outside (open symbols) the gull colony in Surtsey. The line represents Eq. (1) which was fitted to the data. See Table 3 for statistical analysis of the function.

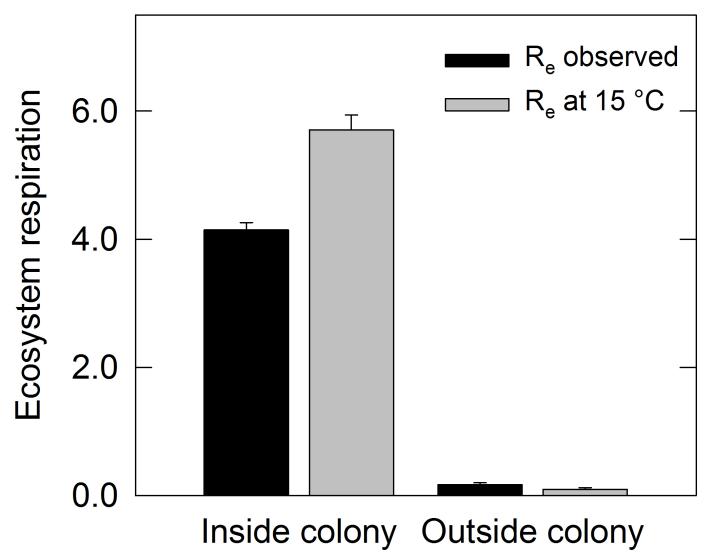

Fig. 4. Average ecosystem respiration $\left(\mu \mathrm{mol} \mathrm{m}{ }^{-2} \mathrm{~s}^{-1} ; \pm \mathrm{SE}, n=8\right.$ and 12) within and outside a gull colony in Surtsey, Iceland. Black bars represent observed rates and grey bars represent the $R_{\mathrm{e}}$ at constant soil temperature of $15^{\circ} \mathrm{C}$.

The high soil $\mathrm{pH}$ observed in Surtsey is typical for Andosols (volcanic soils) in Iceland. Brown Andosols, the dominant soil type of vegetated upland areas, generally have a $\mathrm{pH}$ in the range of 5.5 to 7.5 (Arnalds, 2004). The soil $\mathrm{pH}$ in the gull colony was in the middle of this range. The soil in the

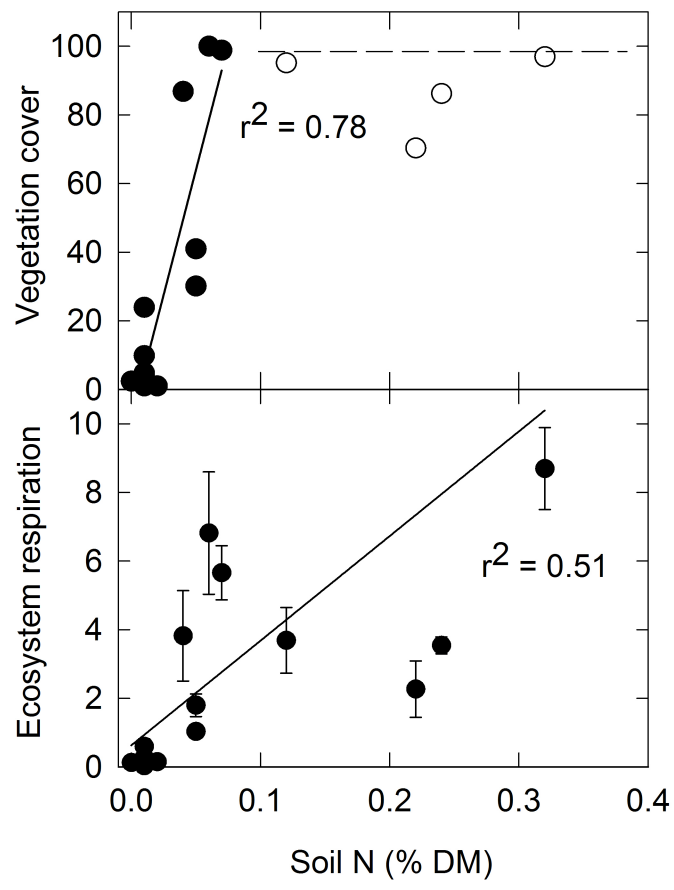

Fig. 5. Vegetation surface cover (top panel; in \%) and ecosystem respiration at $15^{\circ} \mathrm{C}$ (bottom panel; in $\mu \mathrm{mol} \mathrm{CO} \mathrm{Cm}^{-2} \mathrm{~s}^{-1}$ ) in the permanent plots on Surtsey as a function of soil N. Only plots with $\mathrm{N}<0.10 \%$ were included in the regression analysis for vegetation cover (filled symbols). Each point of $R_{\mathrm{e}}$ is an average of 4 measurements \pm SE.

area outside the gull colony, however, had a $\mathrm{pH}$ similar to unvegetated Vitrisols (sandy soils) in Iceland. Their normal $\mathrm{pH}$ range is 7.0 to 7.9 (Arnalds, 2004).

The soil within the gull colony contained $1.7 \% \mathrm{C}$ and had a C:N ratio of 12.7 , only 40 years after Surtsey rose from the sea. This can be compared to an average $\mathrm{C}$ concentration of $3.3 \%$ for Brown Andosols in Iceland (Óskarsson et al., 2004) and C:N ratios of 11-20 (Magnússon et al., 2001; Sigurdsson et al., 2005; Pálmason, 2006). Outside the gull colony the soil contained only $0.04 \% \mathrm{C}$ and had a $\mathrm{C}: \mathrm{N}$ ratio of 5.2, which is low. This C-content was only $10 \%$ of the average $0.39 \%$ C for Icelandic Vitrisols (Óskarsson et al., 2004). The $\mathrm{C}: \mathrm{N}$ ratios in Icelandic Vitrisols and Leptosols (gravelly or stony soils) are commonly found to be higher than was observed in the present study, or between 9 and 11 (Pálmason et al., 1996; Magnússon et al., 2001; Óskarsson and Sigurgeirsson, 2004). However, unvegetated volcanic tephra sands in the vicinity of Mount Hekla in southern Iceland have also been reported to have a $\mathrm{C}: \mathrm{N}$ ratio of 5 (Magnússon et al., 2001).

Nitrogen concentration in the topsoil of denuded Vitrisols and Leptosols in Iceland has been reported as $0.00-0.04 \% \mathrm{~N}$ in various studies (Pálmason et al., 1996; Magnússon et al., 2001; Óskarsson and Sigurgeirsson, 2004). Hence, the low N concentration outside the gull colony on Surtsey was within 
that range. Brown Andosols typically contain 0.10-0.40\% N (Pálmason et al., 1996; Magnússon et al., 2001; Sigurdsson et al., 2005; Pálmason, 2006; Ritter, 2007). The N concentration within the gull colony was on average $0.13 \%$, which is in the lower part of that range.

The present results also showed a clear linear relationship between vegetation cover and the soil $\mathrm{N}$ in the range of 0.0 $0.10 \%$ DM. The increase in vegetation cover and number of plant species within the seagull colony has before been linked to a substantial increase in soil nitrogen originating from the sea and brought to the island by the birds (Magnússon et al., 1996; Magnússon and Magnússon, 2000; Frederiksen et al., 2000). The formation of the gull colony started in 1986 and it was a defining moment in the succession of plant and animal life on the island (Magnússon and Magnússon, 2000). The gulls facilitated colonization of new plant species, probably by carrying seeds to the island. Also they fertilized the sterile soil with their droppings and food brought to the nest sites from the sea. This led to an explosive development of plant and animal communities, including an ever increasing number of invertebrates (Ólafsson and Ingimarsdóttir, 2009), lichens (Kristinsson and Heidmarsson, 2009) and fungal species (Eyjólfsdóttir, 2009). In the past 15 years extensive swards of grasses and forbs have been formed within the area affected by the gulls, but vegetation development on other parts of the island has remained slow by comparison (Magnússon and Magnússon, 2000; Magnússon et al., 2009).

We measured the $\mathrm{CO}_{2}$ efflux from as undisturbed surfaces as possible. The $R_{\mathrm{e}}$ was made out of aboveground plant and root respiration (autotrophic respiration) and respiration of decomposing dead organic matter as well as by metabolism of microbes and fauna (heterotrophic respiration). The present results on $R_{\mathrm{e}}$ highlight how important the nutrient inputs from the seagulls have been for the biological activity on Surtsey. The $R_{\mathrm{e}}$ values measured in the gull colony were among the highest encountered in terrestrial ecosystems in Iceland (e.g. Óskarsson, 1998; Sigurdsson, 2001; Beckmann et al., 2004; Bjarnadottir et al., 2009) and are comparable to maximum values encountered in agricultural croplands and temperate grasslands (Falge et al., 2002) or in fertile Icelandic wetlands (Óskarsson, 1998).

Of the parameters included in the present study, soil nitrogen status explained most of the observed variation in the temperature-corrected $R_{\mathrm{e}}(51 \%)$, which was linearly related to $\mathrm{N}$ over the whole range encountered $(0.0-0.35 \% \mathrm{~N})$. Such a positive relationship was also found by Halvorson et al. (1991), who studied how primary succession and soil respiration were affected by colonization of a nitrogen-fixing Lupinus species on pyroclastic deposits created in the 1980 eruption of Mount St. Helens, WA, USA.

One earlier study involving measurements of soil respiration has been done on Surtsey where Magnússon (1992) used an alkali absorption method to measure soil respiration in areas with three different surface types, bare sand, $13 \% \mathrm{H}$. peploides cover and $21 \%$ L. arenarius cover. This method
Table 3. Regression constants (averages \pm Sd), $Q 10$ value and the statistical outcome of the temperature function for ecosystem respiration per unit of vegetation cover $\left(R_{\mathrm{e}} / V\right)$ inside and outside the gull colony and when the areas had been merged (as shown in Fig. 3).

\begin{tabular}{lccc}
\hline Parameter & $\begin{array}{c}\text { Inside } \\
\text { the colony }\end{array}$ & $\begin{array}{c}\text { Outside } \\
\text { the colony }\end{array}$ & Both areas \\
\hline $\begin{array}{l}\text { Derived constants } \\
R_{0}\end{array}$ & $0.001 \pm 0.001$ & $0.018 \pm 0.173$ & $0.004 \pm 0.002$ \\
$\beta$ & $0.257 \pm 0.095$ & $0.152 \pm 0.055$ & $0.167 \pm 0.032$ \\
$Q 10$ & 13.1 & 4.58 & 5.32 \\
Model statistics & & & \\
ANOVA & 0.008 & 0.002 & $<0.001$ \\
$r^{2}$ & 0.19 & 0.19 & 0.30 \\
Normality test & Passed & Passed & Passed \\
\hline
\end{tabular}

does not give absolute values but rather a relative measure of respiration intensity between measured sites (Reiners, 1968; Magnússon, 1992). The direction of the error is dependent on the flux rate, but typically it overestimates respiration at low rates (Óskarsson, 1998). When converted to molar units, Magnússon (1992) measured on average 0.55, 0.70 and $1.78 \mu \mathrm{mol} \mathrm{CO}_{2} \mathrm{~m}^{-2} \mathrm{~s}^{-1} R_{\mathrm{e}}$ from the bare, $H$. peploides and $L$. arenarius surfaces, respectively. These rates are somewhat higher than those measured in situ from similar surfaces in the present study. Bare sand (plot 21) had on average $0.30 \mu \mathrm{mol} \mathrm{CO} \mathrm{m}^{-2} \mathrm{~s}^{-1} R_{\mathrm{e}}$ in the present study. If we correct the flux values of Magnusson (1992) so that bare sand has a similar in situ respiration rate as found in 2004, then the $H$. peploides and L. arenarius surfaces had comparable respiration rates, as were determined in partly vegetated plots outside the gull colony in the present study.

Since Surtsey is a young volcanic island it was expected that $\mathrm{CO}_{2}$ flux measurements might be affected by degassing of $\mathrm{CO}_{2}$ of volcanic origin. No indications of degassing were found in any of the plots. Completely unvegetated sandy areas had a very low $R_{\mathrm{e}}$ or none, and measurements done on porous lava surfaces did not give any readings.

The observed temperature sensitivity $(Q 10)$ of $R_{\mathrm{e}}$ was rather high, or 5.3. Median aboveground plant $Q 10$ is typically close to 2.3 (Larigauderie and Korner, 1995; Atkin et al., 2005). Soil or ecosystem respiration measured in boreal or sub-arctic ecosystems has rarely shown higher $Q 10$ values than ca. 4.5 (Boone et al., 1998; Atkin et al., 2005). The global average $Q 10$ of soil respiration is reported as 2.4 , even if it is well known that the values become higher in colder soils (Raich and Schlesinger, 1992). The high $Q 10$ values in Surtsey may reflect the high latitude and/or be a result of low-quality substrates, which have been found to be mineralized with a higher $Q 10$ than labile substrates (Larionova et al., 2007). 
Ecosystem respiration is known to vary across diurnal, seasonal and inter-annual time scales due to its sensitivity to the physical and chemical environment, especially fluctuations in temperature (e.g., Atkin et al., 2005). There are, however, other factors which control $R_{\mathrm{e}}$ over longer timescales (weekly, monthly, seasonal), such as soil water availability, growth phenology (autotrophic respiration) and microbe and soil animal population dynamics (heterotrophic respiration) (Raich and Schlesinger, 1992; Atkin et al., 2005; Larionova et al., 2007). The present study took place during two summer days and its results should therefore be interpreted with certain care. However, bearing in mind the 59 -fold difference in $R_{\mathrm{e}}$ between the two contrasting areas when compared at constant temperature, the authors find it unlikely that diurnal or even seasonal fluctuations in temperature could reverse the general pattern found in the study. Even though the vegetated soils were considerably colder during the relatively warm days of the study, their insulating vegetation cover may conserve heat during colder periods, such as during cool nights or autumns. Then the difference in $R_{\mathrm{e}}$ would become even greater between the two areas.

Low water retention of the volcanic substrate can lead to water stress episodes during dry spells. Another recent study on Surtsey by Sigurdsson (2009) indicated that $R_{\mathrm{e}}$ is also affected by water stress. Therefore soil water status should be modelled and used as a driving variable with temperature and soil $\mathrm{N}$ to estimate the annual $R_{\mathrm{e}}$ fluxes. Another point to consider would also be the amount of accumulated substrate for soil respiration. For that, measurements of soil depth and bulk density would be needed in addition to the $\mathrm{C}$ concentration. An indication of the effect of organic matter accumulation was detected in plot 6 in the present study. The plot is located where the seagulls first colonized the lava and where plant succession and soil organic matter accumulation has gone furthest (Magnússon et al., 2009). The plot had the highest $R_{\mathrm{e}}$ fluxes encountered in the present study. The fact that $R_{\mathrm{e}}: T_{\mathrm{S}}$ relationship more or less converged when $R_{\mathrm{e}}$ of different plots inside and outside the gull colony was expressed per unit vegetation cover, however, does indicate that such offsets of $R_{\mathrm{e}}$ by substrate accumulation is still not so important.

It is useful to study how biological activity changes in the early stages of primary succession of a pristine volcanic island like Surtsey. First, pioneering plants have to become established on the sterile surface. They accumulate atmospheric carbon (organic matter) with photosynthesis and absorb soil nutrients into their living tissues. Their dead tissues create the soil organic matter and improve soil fertility, which allows more nutrient and moisture demanding species to colonize. Such a development has generally been believed to take a long time (del Moral and Wood, 1993), especially at higher latitudes where the growing season is short. The present study showed, however, how the initial steps of such a development can be much faster than previously expected due to the nutrient transfer of seagulls from sea to land.

\section{Conclusions}

The amount of nitrogen, which was mainly brought in by seagulls, was an important factor for a build-up of high ecosystem fluxes and vegetation succession on Surtsey. The present study showed how ecosystem activity can be enhanced by colonization of animals which are not dependent on the resources of the given ecosystem.

Acknowledgements. The Surtsey Research Society, Institute of Natural History, Mogilsa - Icelandic Forest Research, and the Icelandic Coastguard provided logistical support for the present study. S. H. Magnússon and E. Ólafsson took part in the field measurements and Anette Th. Meier made the elevation map of the island. Two anonymous referees and Roger del Moral are especially thanked for their constructive comments on the manuscript.

Edited by: K. Pilegaard

\section{References}

Arnalds, O.: Volcanic soils of Iceland, CATENA, 56, 3-20, 2004.

Atkin, O. K., Bruhn, D., and Tjoelker, M. G.: Response of plant respiration to changes in temperature: Mechanisms and consequences of variations in $Q 10$ values and acclimation, in: Plant Respiration, edited by: Lambers, H. and Ribas-Carbo, M., Springer, Netherlands, 95-135, 2005.

Beckmann, M., Sheppard, S. K., and Lloyd, D.: Mass spectrometric monitoring of gas dynamics in peat monoliths: effects of temperature and diurnal cycles on emissions, Atmosph. Environ., 38, 6907-6913, 2004.

Bjarnadottir, B., Sigurdsson, B. D., and Lindroth, A.: A young afforestation area in Iceland was a moderate sink to $\mathrm{CO}_{2}$ only a decade after scarification and establishment, Biogeosciences, 6 , 2895-2906, 2009,

http://www.biogeosciences.net/6/2895/2009/.

del Moral, R. and Wood, D. M.: Early primary succession on the volcano Mount St. Helens, J. Veg. Sci., 4, 223-234, 1993.

Ellis, J. C.: Marine birds on land: A review of plant biomass, species richness, and community composition in seabird colonies, Plant Ecol., 181, 227-241, 2005.

Eyjólfsdóttir, G. G.: Investigation of the funga of Surtsey 2008, Surtsey Res., 12, 105-111, 2009.

Larigauderie, A. and Korner, C.: Acclimation of Leaf Dark Respiration to Temperature in Alpine and Lowland Plant Species, Ann. Bot., 76, 245-252, 1995.

Falge, E., Baldocchi, D., Tenhunen, J., Aubinet, M., Bakwind, P., Berbigier, P., Bernhofer, C., Burba, G., Clement, R., Davis, K. J., Elbers, J. A., Goldstein, A. H., Grelle, A., Granier, A., Guðmundsson, J., Hollinger, D., Kowalski, A. S., Katul, G., Law, B. E., Malhi, Y., Meyers, T., Monsons, R. K., Mungert, J. W., Oechel, W., Paw, K. T., Pilegaard, K., Rannik, U., Rebmanny, C., Suyker, A., Valentini, R., Wilson, K., and Wofsy, S.: Seasonality of ecosystem respiration and gross primary production as derived from FLUXNET measurements, Agr. Forest Meteorol., 113, 53-74, 2002.

Frederiksen, H. B., Pedersen A. L., and Christensen, S.: Substrate induced respiration and microbial growth in soil during primary succession on Surtsey, Iceland, Surtsey Res., 11, 29-35, 2000. 
Fridriksson, S.: The pioneer species of vascular plants in Surtsey, Cakile edentula, Surtsey Res. Progr. Rep., 2, 63-65, 1966.

Fridriksson, S.: Vascular plants on Surtsey 1981-1990, Surtsey Res. Progr. Rep., 10, 17-30, 1992.

Grace, J.: Carbon cycle, Encyclopedia of Biodiversity, 1, 609-628, 2001.

Halvorson, J. J., Smith, J. L., and Franz, E. H.: Lupine influence on soil carbon, nitrogen and microbial activity in developing ecosystems at Mount St. Helens, Oecologia, 87, 162-170, 1991.

Henriksson, L. E. and Rodgers, G. A.: Further studies in the nitrogen cycle of Surtsey, 1974-1976, Surtsey Res. Prog. Rep., 8, 30-40, 1978.

Henriksson, L. E. and Henriksson, E.: Concerning the biological nitrogen fixation on Surtsey, Surtsey Res. Prog. Rep., 9, 9-12, 1982.

Hermannsson, S.: Introduction, Surtsey Res., 12, 5-6, 2009.

Jakobsson, S. P., Magnússon, B., Ólafsson, E., Thorvardardóttir, G., Gunnarsson, K., Baldursson, S., and Petersen, A. E.: Nomination of Surtsey for the UNESCO World Heritage List, edited by: Baldursson, S. and Ingadóttir, A., Icelandic Institute of Natural History, Reykjavik, 124 pp., 2007.

Jóhannsson, B.: Bryological observation on Surtsey, Surtsey Res. Progr. Rep., 4, p. 61, 1968.

Klamer, M., Sponring, A., and Bååth, E.: Microbial biomass and community composition in soils from Surtsey, Iceland, studied using phospholipids fatty acid analysis, Surtsey Res., 11, 37-42, 2000.

Kristinsson, H.: Studies on lichen colonization in Surtsey 1970, Surtsey Res. Progr. Rep., 6, 77-78, 1972.

Kristinsson, H. and Heidmarsson, S.: Colonization of lichens on Surtsey 1970-2006, Surtsey Res., 12, 81-104, 2009.

Larionova, A. A., Yevdokimov, I. V., and Bykhovets, S. S.: Temperature response of soil respiration is dependent on concentration of readily decomposable C, Biogeosciences, 4, 1073-1081, 2007 ,

http://www.biogeosciences.net/4/1073/2007/.

Magnússon, B.: Soil Respiration on the volcanic island Surtsey, Iceland, in 1987 in relation to vegetation, Surtsey Res. Prog. Rep., 10, 9-16, 1992.

Magnússon, B. and Magnússon, S. H.: Vegetation succession on Surtsey, Iceland, during 1990-1998 under the influence of breeding gulls, Surtsey Res., 11, 9-20, 2000.

Magnússon, B., Magnússon, S. M., and Guðmundsson, J.: Vegetation succession on the volcanic island Surtsey, Icel. Agric. Sci., 10, 253-272, 1996 (in Icelandic, English summary).

Magnússon, B., Magnússon, S. H., and Sigurðsson, B. D.: Gróðurframvinda í lúpínubreiðum [Vegetation succession in areas colonized by the introduced Nootka lupin (Lupinus nootkatensis) in Iceland], Rala rep., 207, 100 pp., 2001 (in Icelandic; English summary).
Magnússon, B., Magnússon, S. H., and Fridriksson, S.: Development in plant colonization and succession on Surtsey during 1999-2008, Surtsey Res., 12, 57-76, 2009.

Ólafsson, E. and Ingimarsdóttir, M.: The land-invertebrate fauna on Surtsey during 2002-2006, Surtsey Res., 12, 57-76, 2009.

Óskarsson, H.: Icelandic peatlands: Effects of draining on trace gas release. Ph.D thesis, Univ. of Georgia, USA, 138 pp., 1998.

Óskarsson, H., Arnalds, Ó., Gudmundsson, J., and Gudbergsson, G.: Organic carbon in Icelandic Andosols: Geographical variation and impact of erosion, CATENA, 56, 225-238, 2004.

Óskarsson, H. and Sigurgeirsson, A.: Effects of fertilization on tree seedling establishment and growth in a lupin field in southern Iceland, in: Wild and Cultivated Lupins from the Tropics to the Poles, Proceedings from the 10th International Lupin Conference, Laugarvatn, Iceland, 19-24 June 2002, 203-205, 2004.

Pálmason, F.: Nitrogen mineralization in situ and in laboratory in Icelandic Andosol, Icel. Agric. Sci., 19, 3-13, 2006.

Pálmason, F., Porgeirsson, H., Sigurðardóttir, H., Björnsson, H., and Arnalds, Ó.: Níturlosun í jarðvegi [Nitrogen mineralization in soil], Icel. Agric. Sci., 10, 185-208, 1996 (in Icelandic; English summary).

Petersen, A.: Formation of a bird community on a new island, Surtsey, Iceland, Surtsey Res., 12, 133-148, 2009.

Raich, J. W. and Schlesinger, W. H.: The global carbon dioxide flux in soil respiration and its relationship to vegetation and climate, Tellus, 44, 81-99, 1992.

Reiners, V. A.: Carbon dioxide evolution from the floor of three Minnesota forests, Ecol., 49, 471-483, 1968.

Ritter, E.: Carbon, nitrogen and phosphorus in volcanic soils following afforestation with native birch (Betula pubescens) and introduced larch (Larix sibirica) in Iceland, Plant Soil, 295, 239251, 2007.

Sekercioglu, C. H.: Increasing awareness of avian ecological function, Trends Ecol. Evol., 21, 464-471, 2006.

Schwabe, G. H.: On the algal settlement in craters on Surtsey during summer 1968, Surtsey Res. Prog. Rep., 5, 51-55, 1970.

Sigurdsson, B. D.: Environmental control of carbon uptake and growth in a Populus trichocarpa plantation in Iceland, Acta Universitatis Agriculturae Sueciae. Silvestria 174, 64 pp., 2001.

Sigurdsson, B. D.: Ecosystem carbon fluxes of Leymus arenarius and Honckenya pebloides on Surtsey in relation to water availability: A pilot study, Surtsey Res., 12, 77-80, 2009.

Sigurdsson, B. D., Magnusson, B., Elmarsdottir, Á., and Bjarnadottir, B.: Biomass and composition of understory vegetation and the forest floor carbon stock across Siberian larch and mountain birch chronosequences in Iceland, Ann. For. Sci., 62, 881-888, 2005. 